\title{
Pengembangan Usahatani Masyarakat dalam Upaya Restorasi Lahan Gambut di Kampung Misik, Kalimantan Tengah
}

\author{
Emmy U. Antang ${ }^{1}$, Lilies Supriati ${ }^{1}$, Adi Jaya ${ }^{1}$, dan Haris Gunawan ${ }^{2}$ \\ ${ }^{1}$ Fakultas Pertanian, Universitas Palangka Raya \\ ${ }^{2}$ Universitas Riau, Pekan Baru \\ Email: emmyantang@agb.upr.ac.id
}

\begin{abstract}
Abstrak
Kerusakan lahan gambut disebabkan oleh berbagai faktor, diantaranya pemanfaatan dengan membuat saluran-saluran drainase yang berlebihan, sehingga lahan gambut basah menjadi kering, dan rawan untuk kejadian kebakaran berulang. Pemerintah Indonesia membentuk Badan Restorasi Gambut yang bertujuan untuk percepatan pemulihan kawasan dan pengembalian fungsi hidrologis gambut. Kegiatan Pengembangan masyarakat yang dilakukan bertujuan untuk meningkatkan dan mengembangkan pendapatan masyarakat melalui usahatani masyarakat di kawasan target prioritas restorasi gambut. Hasil kegiatan menunjukkan bahwa petani di Kampung Misik mengusahakan lahan dengan tidak melakukan pembakaran. Kegiatan pertanian adalah sayur, buah-buahan, yaitu: jagung manis, melon, gambas, pare, bawang daun, dan cabe. Luas lahan yang diusahakan oleh petani rata-rata $550 \mathrm{~m} 2$, dengan rata-rata pendapatan per periode tanam sebesar Rp. 3.786.417,- atau Rp. 1.262.139,- per bulan, dengan rasio penerimaan dan biaya (R/C) yang paling baik adalah usahatani tanaman pare dengan nilai 7, sedangkan yang terkecil adalah jagung manis, terung, dan melon dengan nilai 3. Penguatan usahatani masyarakat melalui suntikan modal usaha dapat digunakan sebagai modal usahatani berikutnya. Beberapa petani dapat mengembangkan usahataninya dalam bentuk luasan tanam ataupun ragam usahataninya. Pembentukan modal usahatani saat ini telah dimulai dengan adanya kewajiban iuran setiap bulan yang disampaikan dalam pertemuan rutin setiap bulan.
\end{abstract}

Kata kunci: mata pencaharian, usahatani, dan restorasi gambut

\section{Pendahuluan}

Lahan gambut adalah lahan yang memiliki lapisan tanah kaya bahan organik (C-organik > $18 \%$ ) dengan ketebalan $50 \mathrm{~cm}$ atau lebih. Bahan organik penyusun tanah gambut terbentuk dari sisa-sisa tanaman yang belum melapuk sempurna karena kondisi lingkungan jenuh air dan miskin hara. Lahan gambut banyak dijumpai di daerah rawa belakang (back swamp) atau cekungan yang drainasenya buruk (Agus \& Subiksa, 2008).

Gambut terbentuk dari timbunan sisa-sisa tanaman yang telah mati, baik yang sudah lapuk ataupun belum. Timbunan terus bertambah karena proses dekomposisi terhambat oleh kondisi anaerob dan/atau kondisi lingkungan lainnya yang menyebabkan rendahnya tingkat perkembangan biota pengurai. Pembentukan tanah gambut merupakan proses geogenik yaitu pembentukan tanah yang disebabkan oleh proses deposisi dan transportasi, berbeda dengan proses pembentukan tanah mineral yang pada umumnya proses pedogenik (Hardjowigeno, 1986).
Kerusakan lahan gambut disebabkan berbagai faktor, diantaranya adalah pemanfaatan lahan gambut dengan membuat saluran-saluran drainase yang berlebihan, sehingga lahan gambut basah menjadi kering, dan rawan untuk kejadian kebakaran berulang. Kawasan gambut tropika banyak yang mengalami degradasi diantaranya adalah akibat kebakaran hutan dan lahan gambut. Kebakaran hutan dan lahan tahun 2015 merupakan kebakaran hutan dan lahan yang cukup parah dan lama, dan akibat dari kebakaran lahan tersebut makin meluas. Pemerintah Indonesia melalui Peraturan Presiden Nomor 1 Tahun 2016, telah membentuk Badan Restorasi Gambut untuk tujuan melakukan konservasi dan restorasi lahan gambut terdegradasi. Peraturan Pemerintah (PP) Nomor 71 Tahun 2014 tentang Perlindungan dan pengelolaan Ekosistem Gambut dan PP Nomor 57 Tahun 2016 tentang Perubahan atas Peraturan Pemerintah Nomor 71 Tahun 2014 Tentang Perlindungan dan Pengelolaan Ekosistem Gambut, menjadi dasar utama pelaksanaan kegiatan yang berkaitan dengan ekosistem gambut, termasuk kegiatan restorasi gambut yang rusak. 
Dalam hal pemanfaatan oleh masyarakat, gambut digunakan sebagai media tanam untuk kegiatan pertanian. Di kawasan Kalampangan Kalimantan Tengah yang pengembangannya dilakukan pada tahun 70-an, budidaya tanaman di lahan gambut sulit dilakukan dan masyarakat transmigrasi yang ditempatkan di kawasan tersebut mengalami kegagalan. Dan dengan berjalannya waktu masyarakat mampu memperoleh cara melakukan budidaya tanaman, salah satunya dengan memanfaatkan abu hasil bakaran berbagai biomassa di kawasan gambut untuk memperbaiki kualitas lahan gambut. Namun teknologi budidaya seperti ini tentu saja bukan merupakan pertanian yang ramah lingkungan dan berkelanjutan. Dan masyarakat petani baik secara mandiri maupun dengan memanfaatkan hasil-hasil penelitian terus melakukan inovasi dalam melakukan budidaya tanaman di kawasan gambut dan berupaya tidak menggunakan cara yang tidak sustain dengan sistem tanpa bakar tersebut.

Secara umum pendekatan terpadu (terintegrasi) harus dilakukan untuk konservasi dan restorasi lahan gambut terdegradasi sebagaimana menjadi program BRG yaitu $3 \mathrm{P}$ dengan mencakup aspek: restorasi hidrologi: pembasahan (re-wetting) dan penamanan kembali (re-vegetasi), pemberdayaan ekonomi masyarakat (revitalisasi livelihood) serta penyiapan tim pencegahan dan penanggulangan kebakaran hutan dan lahan. Pemberdayaan ekonomi masyarakat masyarakat melalui berbagai kegiatan budidaya tanaman bernilai ekonomis, budidaya ikan, budidaya lebah dll dimaksudkan agar masyarakat tidak melakukan aktivitas perambahan hutan yang juga menyebabkan degradasi hutan dan lahan rawa gambut dan bahkan dapat diarahkan untuk menjaga kawasan hutan apabila mereka memiliki pendapatan tetap untuk kebutuhan ekonomi mereka. Untuk masa depan, kegiatan memanfaatkan nilai jasa lingkungan kawasan hutan sebagai bagian wisata perlu dipertimbangkan.

Tujuan kegiatan pengabdian kepada masyarakat ini adalah:

1. Untuk menerapkan uji coba pola usahatani buah dan sayur dengan sistem tanpa bakar.
2. Untuk menganalisis usahatani buah dan sayur dengan pola usahatani tanpa bakar.

3. Mempelajari penerapan penguatan mata pencaharian petani melalui pemberian insentif modal usahatani.

Manfaat kegiatan pengabdian masyarakat ini adalah:

1. Petani dapat menerapkan pola usahatani buah dan sayur dengan sistem tanpa bakar

2. Mengetahui nilai usahatani buah dan sayur dengan pola usahatani tanpa bakar.

3. Mengetahui dampak dari pemberian insentif modal usahatani kepada petani.

\section{Metode Pelaksanaan Kegiatan}

\section{A. Tempat dan Waktu}

Tempat pelaksanaan di Kampung Misik, Kelurahan Kalampangan Kota Palangka Raya Provinsi Kalimantan Tengah. Pemilihan tempat dilakukan secara sengaja karena wilayah ini merupakan kawasan lahan gambut yang mengalami kebakaran pada tahun 2015. Waktu pengabdian dilaksanakan pada bulan Juli Desember 2018.

\section{B. Bahan dan Alat}

Bahan yang digunakan dalam kegiatan pengabdian ini adalah berupa input produksi untuk usahatani, yaitu:

a) benih: Paria, jagung manis, terong ungu, melon orange, melon biasa, gambas, dan cabe.

b) kapur dolomit;

c) pupuk kandang dan pupuk kimia;

d) obat-obat pengendali pengganggu tanaman.

Peralatan yang diperlukan meliputi alatalat pertanian yang umum digunakan dan merupakan alat-alat milik petani.

\section{Tahapan Pelaksanaan}

Kegiatan pengabdian untuk pengembangan usahtani masyarakat dilakukan melalui beberapa tahapan, yaitu:

a) Sosialisasi;

b) Persiapan dan pelaksanaan Budidaya tanaman sayuran dan buah dengan system tanpa bakar;

c) Penguatan usahatani. 


\section{Hasil Pelaksanaan Kegiatan}

Kampung Misik merupakan daerah bukaan baru dan merupakan bagian dari Kelurahan Kalampangan, yang dikembangkan oleh penduduk setempat mulai tahun 2015, dan wilayah ini mengalami kebakaran lahan yang besar pada tahun 2015. Sejak dibuka tahun 2015 tersebut, kawasan kampung Misik terbebas dari kebakaran lahan. Namun demikian, teknik budidaya yang dilakukan banyak mengadopsi petani kawasan Kalampangan yang merupakan kawasan transmigrasi yang dikembangkan sejak tahun 1979, sehingga tingkat kegagalan budidaya tanaman di kawasan Kampung Misik relatif kecil.

Petani di Kelurahan kalampangan pada umumnya menambahkan abu bakaran pada lahan usahatani, dimaksudkan untuk meningkatkan kesuburan dan memperbaiki struktur tanah. Untuk menghasilkan abu, petani mengumpulkan gulma dan ranting kayu lalu membakarnya di lahan usaha. Akibat dari pembakaran tersebut turut terbakar tanah gambut yang ada dan dapat berdampak pada penurunan tanah. Kegiatan pengabdian ini mengaplikasikan usahatani tanpa menggunakan abu, sebagai penggantinya pada lahan diberikan kapur dan pupuk dasar (pupuk kandang).

\section{Tahap Sosialisasi}

Sosialisasi dilaksanakan untuk memberikan pemahaman tentang tujuan dan manfaat kegiatan kepada masyarakat, dilaksanakan dengan FGD dengan melibatkan ketua RT, tokoh masyarakat, dan masyarakat yang berada di Kawasan Misik. Hasil dari kegiatan sosialisasi adalah kesepakatan masyarakat untuk melaksanakan kegiatan secara bersamasama. Kegiatan sosialisasi dilanjutkan dengan indentifikasi petani yang bersedia terlibat dalam kegiatan, sebanyak 7 orang petani bersedia lahannya digunakan sebagai lokasi demplot kegiatan.

Pada umumnya petani yang berusahatani bukan pemilik lahan, namun hanya sebagai penggarap lahan tanpa harus membayar upah atau membagi hasil. Pemilik lahan mendapatkan manfaat dari lahan yang bersih dan terjaga dari kebakaran lahan. Petani sebagian besar merupakan masyarakat yang menetap di wilayah lama di Kelurahan Kalampangan, dan transmigran yang berasal dari Pulau Jawa.

\section{Tahap Persiapan dan Pelaksanaan Budidaya}

Pada tahap persiapan dilakukan diskusi tentang jenis tanaman dan luasan lahan yang dilakukan ujicoba penanaman dengan teknik tanpa bakar. Hasil diskusi telah disepakati dilakukan ujicoba penanaman 7 (tujuh) jenis sayuran dan buah dengan masing-masing luasan lahan yang berbeda. Pertimbangan pemilihan jenis tanaman adalah permintaan pasar yang saat itu meningkat, sehingga diharapkan ketika tanaman menghasilkan mendapatkan harga yang bagus dan memberikan keuntungan yang baik untuk petani. Setiap petani telah memiliki jadwal pergiran tanaman pada lahannya, kecuali tanaman yang rutin diperlukan masyarakat seperti terong ungu, gambas dan cabe. Penanaman jagung manis dan melon ditanam menjelang hari-hari besar seperti hari raya keagamaan dan tahun baru, karena pada saat tersebut kebutuhan sangat tinggi.

Luasan lahan yang digunakan berkisar antara $200-1.200 \mathrm{~m}^{2}$, dengan luasan terbesar untuk tanaman Paria dan jagung manis, sedangkan yang terkecil adalah untuk tanaman terung ungu dan melon orange.

Teknik budidaya disepakati menggunakan teknik budidaya yang sudah biasa digunakan oleh petani, namun tanpa menggunakan abu bakar dan tanpa teknik membakar pada lahan, sebagai gantinya digunakan dolomit dan pupuk kandang sebagai pupuk dasar sekaligus untuk memperbaiki kondisi tanah.

Untuk meningkatkan kesuburan lahan gambut, petani melakukan pemupukan kimia secara rutin setiap minggu sekali, dengan mencampurkan beberapa jenis pupuk kimia dan melarutkannya dengan air, dan disiramkan pada tanah disekitar tanaman. Jumlah dan kombinasi pupuk 
kimia yang digunakan berbeda antara petani yang satu dengan petani yang lain, didasarkan pada pengalaman masingmasing petani. Pupuk yang digunakan NPK (Mutiara), $\mathrm{KCl}$, Ponska, Urea, dan Green Tonik.

Pemberian obat-obat tanaman untuk mengobati hama dan penyakit tanaman dilakukan secara rutin, dan intensitas pemberiannya disesuaikan dengan serangan hama dan penyakit tanaman. Cara penggunaan obat-obat tanaman adalah dengan melarutkannya dengan air lalu disemprotkan kepada bagian tanaman.
Tidak berbeda dengan pemberian pupuk, jumlah dan kombinasi obat-obatan yang digunakan berbeda antara satu petani dengan petani yang lain, tergantung kepada pengalaman petani dan kebutuhan tanaman. Obat-obatan yang digunakan adalah Sixlon, Bion M, Score, Antracol, Acrobat, Napir Plus, Demolist dan Alika.

Tenaga kerja yang digunakan oleh petani adalah tenagakerja dalam keluarga, hanya beberapa petani dengan lahan yang luas menggunakan tenaga kerja luar keluarga untuk membantu pemanenan.

Tabel 1. Luas, jenis, dan produksi tanaman yang diusahakan

\begin{tabular}{lccc}
\hline \multirow{1}{*}{ Jenis Tanaman } & Luas Tanam & \multicolumn{2}{c}{ Produksi } \\
\cline { 3 - 4 } & $(\mathrm{m} 2)$ & Jumlah & Satuan \\
\hline Paria & 1.200 & 585 & $\mathrm{Kg}$ \\
Jagung Manis_1 & 1.200 & 2.500 & Tongkol \\
Jagung Manis_2 & 200 & 1.000 & Tongkol \\
Terung Ungu & 200 & 525 & $\mathrm{Kg}$ \\
Melon Orange & 200 & 1.200 & $\mathrm{Kg}$ \\
Melon Biasa & 500 & 1800 & $\mathrm{Kg}$ \\
Gambas & 300 & 1.270 & $\mathrm{Kg}$ \\
Cabe & 500 & 300 & $\mathrm{Kg}$ \\
\hline
\end{tabular}

Dibandingkan dengan pengolahan lahan dengan membakar untuk menghasilkan abu bakar, usahatani dengan teknik tanpa bakar menunjukkan hasil yang tidak berbeda dengan teknik bakar. Hasil ini memberikan pengetahuan dan pemahaman baru kepada petani, bahwa tanpa membakar pun mereka bisa mendapatkan hasil yang baik. Berikut foto tanaman dan hasilnya yang diusahakan oleh petani dengan teknik tanpa bakar.

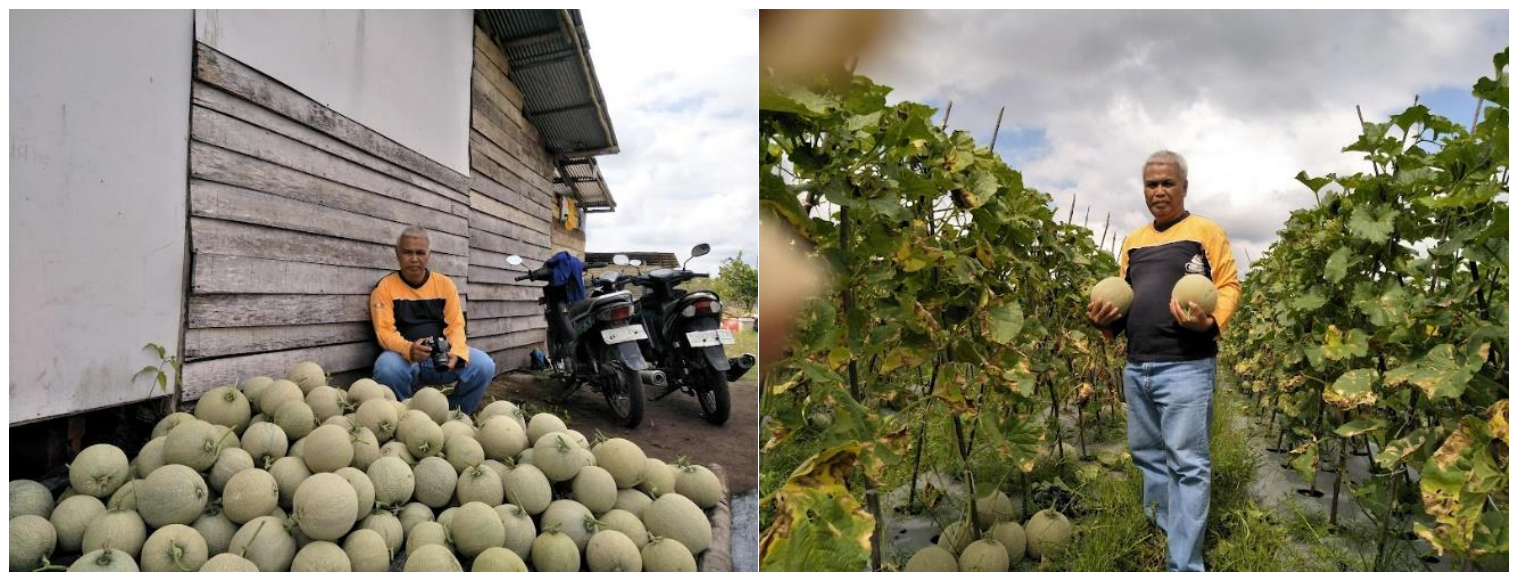

Gambar 1. Tanaman dan Hasil Produksi Melon 
Tanaman melon dibudidayakan selama 3 (tiga) bulan. Tanaman Melon memberikan hasil yang baik, baik dari pertumbuhan vegetative maupun produksi buah melon. Besar maupun berat buah yang dihasilkan tidak menunjukkan perbedaan dengan usahatani sebelumnya. Petani melakukan pengukuran terhadap ukuran besar buah dan berat buah yang dibandingkan dengan produksi sebelumnya.
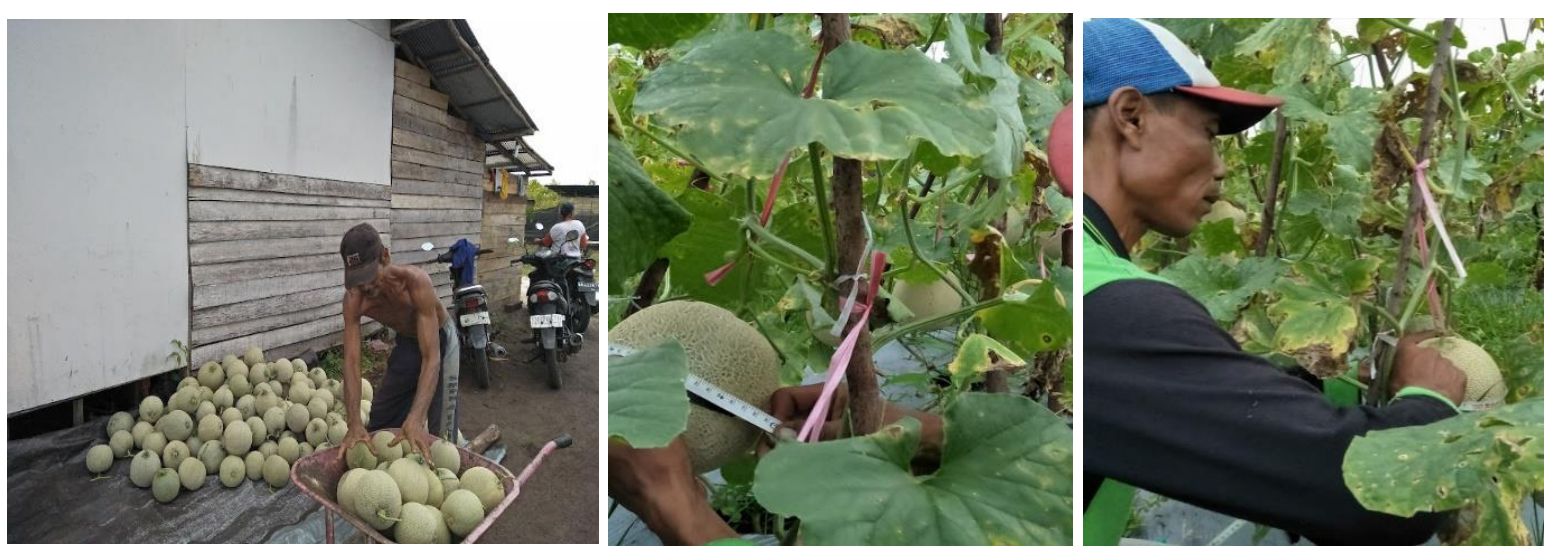

Gambar 2. Petani melakukan pemanenan dan pengukuran besar buah Melon

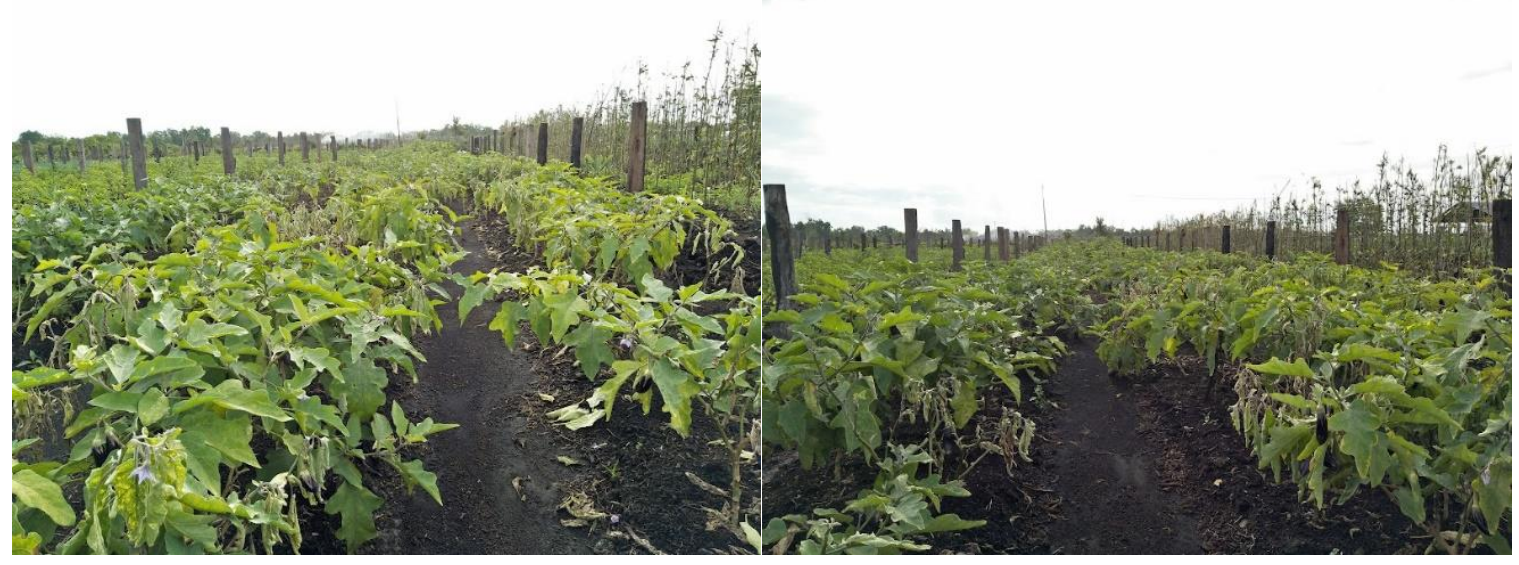

Gambar 3. Tanaman Terong Ungu

Tanaman Terong ungu diusahakan pada lahan gambut yang baru dibuka oleh petani, biasanya petani menggunakan abu bakar untuk menetralkan keasaman lahan. Namun pada kegiatan pengabdian ini tidak menggunakan teknik menggunakan teknik abu bakar. Hasil produksi yang ditunjukkan dari demplot menggunakan budidaya tanpa bakar baik pertumbuhan vegetative maupun hasil produksinya tidak menunjukkan perbedaan yang signifikan.

Gambas merupakan sayuran yang rutin diusahakan oleh petani, yang memberikan keuntungan kepada petani baik hasil dari daun maupun buah. Oleh karenanya tanaman gambas perlu memperhatikan daunnya juga. 


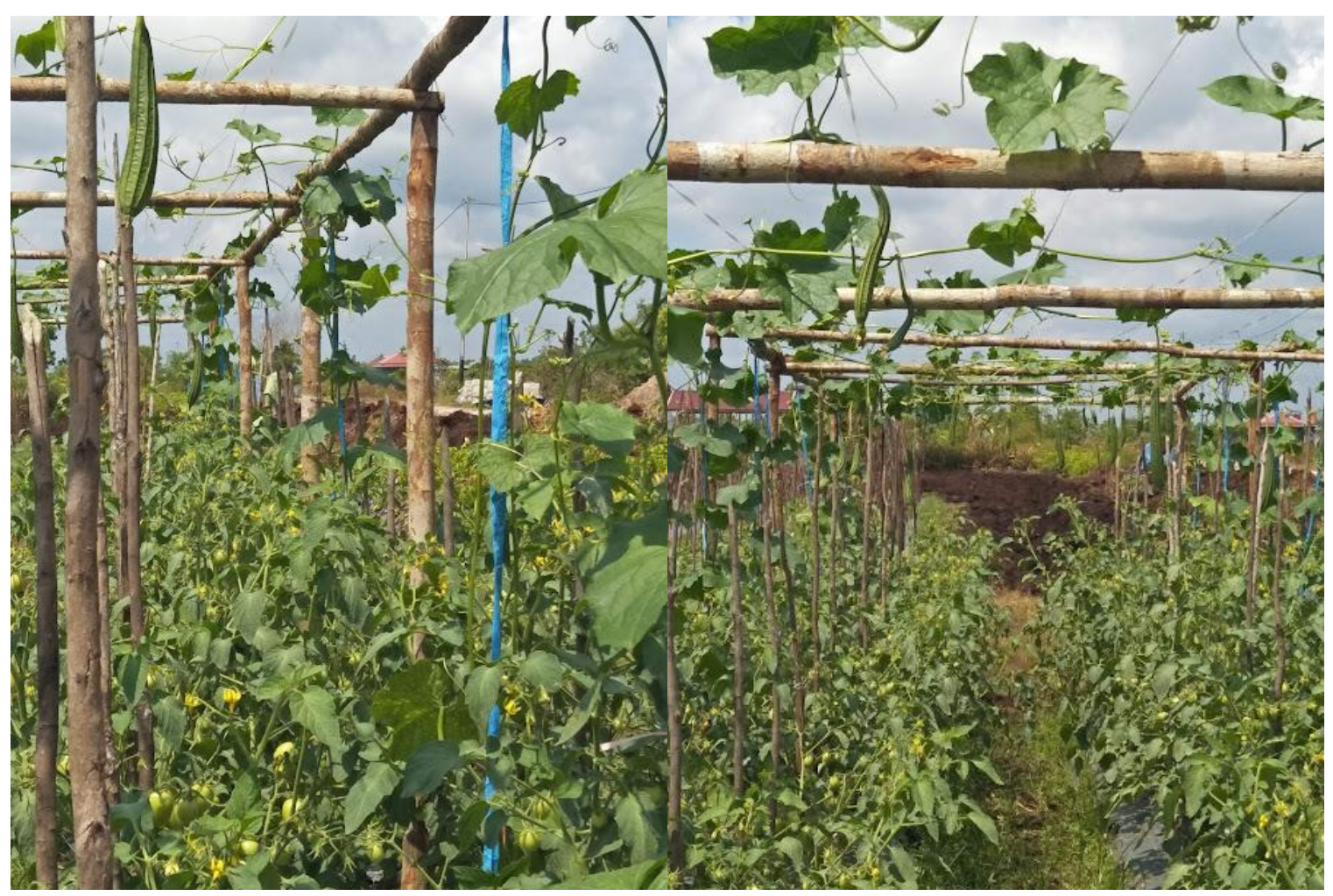

Gambar 4. Tanaman Gambas
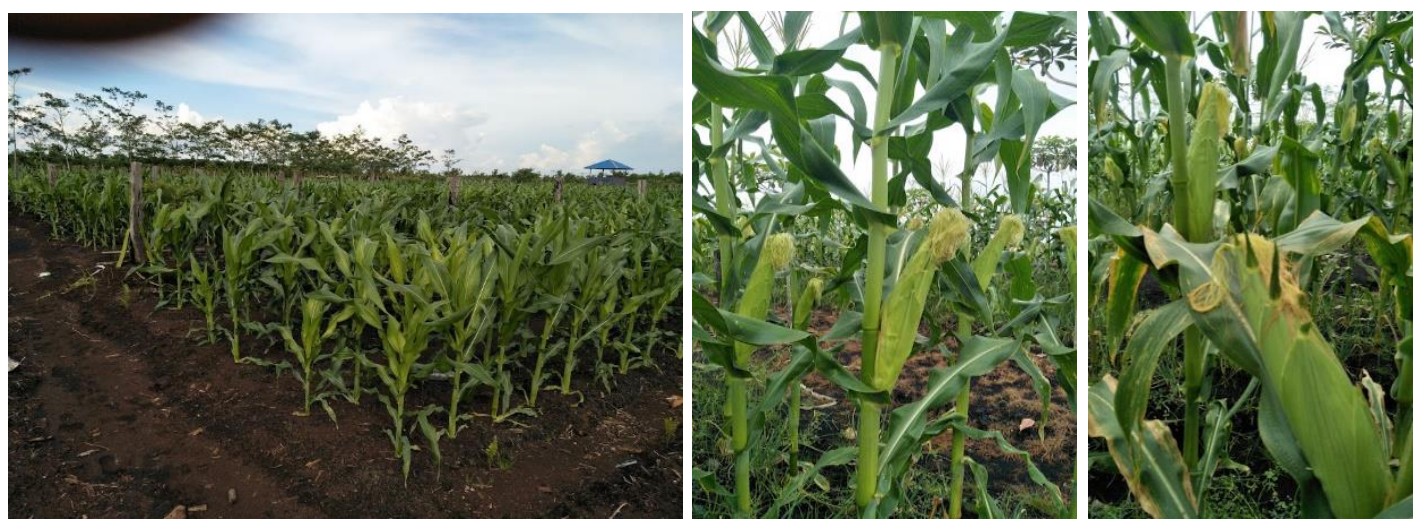

Gambar 5. Tanaman Jagung

Tabel 2. Biaya, penerimaan, pendapatan, dan rasio penerimaan-pendapatan $(\mathrm{R} / \mathrm{C})$ tanaman yang diusahakan

\begin{tabular}{lcccc}
\hline \multicolumn{1}{c}{ Jenis Tanaman } & $\begin{array}{c}\text { Biaya } \\
(\mathrm{Rp})\end{array}$ & $\begin{array}{c}\text { Penerimaan } \\
(\mathrm{Rp})\end{array}$ & $\begin{array}{c}\text { Pendapatan } \\
(\mathrm{Rp})\end{array}$ & $\mathrm{R} / \mathrm{C}$ \\
\hline Paria & 566.000 & 3.910 .000 & 3.344 .000 & 7 \\
Jagung Manis_1 & 818.000 & 5.000 .000 & 4.182 .000 & 6 \\
Jagung Manis_2 & 757.500 & 2.000 .000 & 1.242 .500 & 3 \\
Terung Ungu & 1.035 .000 & 3.150 .000 & 2.115 .000 & 3 \\
Melon Orange & 2.470 .000 & 8.400 .000 & 5.660 .000 & 3 \\
Melon Biasa & 2.440 .000 & 6.450 .000 & 4.010 .000 & 3 \\
Gambas & 1.845 .000 & 7.620 .000 & 5.775 .000 & 4 \\
Cabe & 995.000 & 3.000 .000 & 2.005 .000 & 3 \\
\hline
\end{tabular}


Biaya produksi dari setiap jenis tanaman bervariasi antara Rp. 566.000- Rp.2.470.000, biaya terkecil adalah biaya tanaman paria, dan yang terbesar untuk biaya tanaman melon orange. Hasil pengabdian ini menunjukkan bahwa kecil-besarnya biaya produksi tidak tergantung pada luas tanam tapi dipengaruhi oleh jenis tanaman.

Tabel 2 menunjukkan pula bahwa untuk jenis tanaman yang sama, jagung manis yang diusahakan petani 1 yang berbeda 6 kali lebih besar luas tanamnya dibandingkan petani 2 tidak menunjukkan bahwa biaya produksi lebih besar 6 kali, biaya produksi hanya berbeda 1,08 kali. Jika memperhatikan produksi jagung manis yang dihasilkan seperti ditampilkan pada tabel1 menunjukkan bahwa besar produksi hanya 2,5 kali.

Pada tanaman melon, antara melon orange dan melon biasa menunjukkan luas tanam melon biasa 2,5 kali lebih besar dibandingkan dengan melon orange, namun biaya produksi melon orange hampir sama dengan biaya produksi melon biasa. Produksi melon biasa lebih besar 1,5 kali dari melon orange.

Penerimaan dipengaruhi oleh jumlah produksi dan harga produk, berkisar antara Rp. 2.000.000-Rp. 8.400.000. Penerimaan terkecil adalah petani 2 yang menanam jagung manis dan penerimaan yang paling besar adalah petani yang menanam melon orange.

Penerimaan dan pendapatan petani bervariasi berdasarkan luas lahan dan jenis tanaman yang diusahakan. Buah melon orange dengan luasan hanya $200 \mathrm{~m} 2$ membutuhkan biaya produksi yang paling besar dibandingkan jenis tanaman yang lain, bahkan jika dibandingkan dengan paria dan jagung manis_1 dengan luas tanam $1.200 \mathrm{~m} 2$, namun memberikan penerimaan dan pendapatan yang relatif lebih besar dibandingkan dengan jenis tanaman lainnya, kecuali gambas.

Tanaman gambas dengan luas tanam 200m2 membutuhkan biaya sedikit lebih kecil dibandingkan melon, namun memberikan nilai pendapatan relatif lebih besar dibandingkan dengan semua jenis tanaman lainnya. Besarnya penerimaan petani melon orange dibandingkan dengan petani melon biasa disebabkan harga jual melon orange jauh lebih besar dibandingkan dengan harga jual melon biasa. Harga jual melon biasa rata-rata Rp. $3.250 / \mathrm{kg}$ sedangkan melon orange dijual pada harga Rp.10.000/kg. Sehingga walaupun biaya produksi melon orange lebih besar dari melon biasa namun penerimaan petani orange lebih besar daripada petani melon biasa.

Pendapatan ditentukan oleh penerimaan dan biaya usahatani, Pendapatan petani partisipan bervariasi dari Rp. 1.242.500Rp. 5.775.000 untuk setiap kali produksi, atau Rp. 400.000-Rp. 1.132.000 per bulan. yang terkecil adalah pendapatan usahatani jagung manis petani 2 dan yang terbesar didapat dari usahatani gambas.

Nilai R/C menunjukkan bahwa semua usahatani efisien dan layak dikembangkan, usahatani paria paling efisien dibandingkan dengan usaha tani tanaman lain $(\mathrm{R} / \mathrm{C}=6)$, diikuti oleh usaha tani jagung manis petani $1(\mathrm{R} / \mathrm{C}=6)$, dan usahatani gambas $(\mathrm{R} / \mathrm{C}=4)$. Menarik untuk membandingkan tingkat efisiensi usahatani jagung manis antara petani $1(\mathrm{R} / \mathrm{C}=6)$ dengan petani $2(\mathrm{R} / \mathrm{C}=3)$ yang menunjukkan bahwa pemberian input produksi yang tinggi tidak menghasilkan produksi yang tinggi pula. Sehingga perlu untuk memperhatikan dosis pemupukan dan obat-obatan yang diberikan kepada tanaman.

Hasil pendampingan terhadap usahatani secara keseluruhan menunjukkan bahwa petani dapat menghasilkan produksi pertanian dengan jumlah yang baik dengan tidak menggunakan abu, tapi menggantinya dengan penggunaan kapur dolomit dan pupuk kandang. Dengan demikian, kerusakan lahan gambut akibat pembakaran untuk menghasilkan abu bakar dapat dihindari. Agus \& Subiksa (2008) menyatakan bahwa pemberian kapur dan pupuk kandang merupakan salah satu strategi untuk pengelolaan kesuburan tanah untuk tanaman pangan. Selanjutnya, Ambak et al 
(1991) menyatakan bahwa pemberian kapur dan pupuk mikro meningkatkan produksi jagung. Sedangkan Chua dan Faridah (1991) menyatakan makin tinggi input produksi berupa kapur dan pupuk yang diberikan maka produksi tanaman hortikultura meningkat tajam.

Petani cenderung memberikan pupuk dan obat-obat pertanian berlebihan, yang berakibat menurunnya efisiensi usahatani. Agus \& Subiksa (2008) menyatakan bahwa dosis anjuran penggunaan amelioran pada lahan gambut adalah kapur sebanyak 1-2 ton/ha/tahun, dan pupuk kandang 5-10 ton/ha/tahun.

Suntikan modal usahatani yang diberikan merupakan insentif kepada petani pada kawasan yang melaksanakan restorasi gambut, khususnya pada wilayah yang melaksanakan R1 dan R2. Insentif ini terbukti memberikan penguatan usahatani kepada petani dengan mengembangkan usahatani dalam bentuk penambahan luas tanam dan ragam usahatani. Beberapa petani telah mengembangkan luasan areal tanam dari pengembangan modal yang diberikan, dan petani lainnya mengembangkan usahataninya dengan jenis tanaman lain pada lahan tanam yang sama tanpa harus memberikan kapur dan pupuk kandang lagi sebagai amelioran.

Modal usahatani yang diberikan kepada petani partisipan terus dikembangkan,

kesadaran untuk mengembangkan modal usaha tani telah dimulai bahkan kepada petani lain dengan menginisiasi iuran wajib setiap bulan untuk penyediakan input produksi berupa kapur, pupuk dan obat-obat pertanian. Selain itu, penguatan modal sosial menjadi penting untuk pengembangan usahatani masyarakat, terutama untuk peningkatan mata pencaharian masyarakat melalui pengembangan usahatani namun tetap menjaga kelestarian lingkungan, khususnya pada lahan gambut.

\section{Kesimpulan dan Saran \\ Kesimpulan}

Kesimpulan dari hasil pendampingan usahatani ini adalah:

1. Petani partisipan dapat mengaplikasikan usahatani dengan tidak menggunakan abu bakar atau pembakaran, dan menggantinya dengan kapur dolomit dan pupuk kandang.

2. Semua jenis tanaman memberikan keuntungan dan menghasilkan pendapatan petani dengan kisaran antara Rp. 1.242.500-Rp. 5.775.000 per periode tanam, dengan nilai $\mathrm{R} / \mathrm{C}>1$ untuk seluruh jenis tanaman, dengan kisaran $\mathrm{R} / \mathrm{C}$ antara 3-7.

3. Penguatan modal sosial masyarakat menjadi bagian penting dalam mendukung penguatan modal usahatani dan pengembangan mata pencaharian masyarakat dengan tetap menjaga kelestarian lingkungan.

\section{Saran}

Saran yang dapat diberikan dari hasil pendampingan ini adalah perlu melakukan perhitungan tentang penggunaan pupuk, baik jumlah maupun kombinasinya yang sesuai dengan tahap pertumbuhan tanaman, sehingga dapat memberikan efisiensi usahatani yang baik.

\section{Ucapan Terimakasih}

Ucapan terima kasih disampaikan kepada Badan Restorasi Gambut yang telah mendanai kegiatan melalui Tahun Anggaran 2018.

\section{Daftar Pustaka}

Agus, F, I.G. M. Subiksa. (2008). Lahan Gambut: Potensi untuk Pertanian dan Aspek Lingkungan. Bogor: Balai Penelitian Tanah dan World Agroforestry Centre (ICRAF) Indonesia.

Ambak K, Zahari AB, Tadano T. (1991). Effect of micronutrient application on the growth of crop plants and on the occurrence of crop sterility I Malaisya peat soil. Precceding of the International 
Symposium on Tropical Peatland. Kuching Serawak 6-10 May 1991. p399409

Badan Restorasi Gambut. (2016). Rencana Strategis Badan Restorasi Gambut 20162020. Jakarta: Badan Restorasi Gambut.

Chua AK, Faridah A, (1991). Liming of peat for some vegetable in Johor, Malaisyain. Precceding of the International Symposium on Tropical Peatland.
Kuching Serawak 6 - 10 May 1991. p 393-398.

Hardjowigeno, S. (1986). Sumber daya fisik wilayah dan tata guna lahan: Histosol.Bogor: Fakultas Pertanian Institut Pertanian Bogor. Soekartawi. (1995). Analisis Usahatani. Jakarta: Universitas Indonesia.

Soetrisno. (1988). Analisis Usahatani. Jakarta: Direktorat jenderl Tanaman Pangan. 